\title{
Environmental Aspects and Public Concern for the Environment as Part of Sport Diplomacy at the 2018 Asian Games
}

\author{
Nur Aslamiah Supli ${ }^{1}$,Inda Mustika Permata ${ }^{2}$, Retno Susilowati ${ }^{1}$ \\ 1 \\ Sriwijaya University, Palembang, Indonesia \\ ${ }^{2}$ Andalas University, Padang, Indonesia \\ *corresponding author email: nur.supli@ unsri.ac.id
}

Article history

\begin{tabular}{llll} 
Received & Received in revised form & Accepted & Available online \\
21 June 2020 & 06 July 2020 & 16 August 2020 & 31 August 2020 \\
\hline
\end{tabular}

\begin{abstract}
The environmental aspects and the community's environmental concern are an inseparable part of the Sports Diplomacy at the 2018 Asian Games. This study is aimed at examining the environmental aspects and environmental concerns of the community. Researchers used explorative and descriptive methods. The sampling technique in this study is purposive sampling. Data were gathered using online questionnaires in a google form for likert scale 1-5. The results showed that all the public facilities were considered to be sufficient for visitors to the Jakabaring Sport city during the 2018 Asian Games. Based on the asked opinions with likert scales 1-5 it was found that the respondents' opinions on the environmental aspects of the games' facilities were quite good to very good, which included the availability of clean water, garbage boxes, availability of public toilets and smoke-free zones. Less than 10 percent of respondents are concerned about the adequacy of clean water and other public facilities.

Key words: Environmental aspects, Asian Games, Environmental concern, sport diplomacy.
\end{abstract}

Abstrak: Aspek lingkungan dan kepedulian lingkungan masyarakat merupakan bagian yang tidak terpisahkan dari Diplomasi Olahraga di Asian Games 2018. Kajian ini bertujuan untuk mengkaji aspek lingkungan dan kepedulian lingkungan masyarakat. Peneliti menggunakan metode eksploratif dan deskriptif. Teknik pengambilan sampel dalam penelitian ini adalah purposive sampling. Data dikumpulkan dengan menggunakan kuesioner online dalam bentuk google untuk skala likert 1-5. Hasil penelitian menunjukkan bahwa semua fasilitas umum dinilai sudah cukup memadai bagi pengunjung Jakabaring Sport City selama Asian Games 2018 berlangsung. Berdasarkan pendapat yang ditanyakan dengan skala likert 1-5 didapatkan bahwa pendapat responden terhadap aspek lingkungan sarana permainan cukup baik sampai sangat baik yang meliputi ketersediaan air bersih, kotak sampah, ketersediaan WC umum. dan zona bebas asap rokok. Kurang dari 10 persen responden mengkhawatirkan kecukupan air bersih dan fasilitas umum lainnya

Katakunci : Aspek Lingkungan, Asian Games, Kepedulian Lingkungan, Diplomasi Olahraga

\section{Introduction}

Sports diplomacy has been used to improve a country's image abroad hence the better relationship between countries since the Olympics in Ancient Greece. Sports as diplomacy can be used as a tool for confrontation when relations between countries are not good or when starting a relationship between countries, sports can make and facilitate the diplomacy process [1]. Sports diplomacy has many variants due to the presence of sports variants in the world. Sports diplomacy has also often been proven to be helpful in reducing conflicts and tensions between countries, especially countries in conflict. As in the example of Pingpong Diplomacy between America and China in 1972. At that time the American President was Richard Nixon and China was led by the communist party Mao Zedong. At that time, it was the moment when America first stepped on the Chinese earth since the communist party took the lead in a friendly table tennis match. Two months later China alternately came to visit America. The table tennis match helped the diplomatic process between America and China [2].

Judit and Bob (2017) on their paper Sport Diplomacy : A Review of How Sport Can be Used to Improve International Relations argued that there are 7 (seven) benefits from used sport as platform diplomacy such as 1) Providing reasons for leaders of countries to meet and begin a dialogue, 2) Providing facilities to introduce and educate others about host country, 3) Helping on bridging cultural and linguistic differences among nation through sport, 4) Make a new platform for new agreement or legislation on trading, 5) create sport ambassadors who can promote awareness for international relationship, 6) as a tool for new branding and new legacy for the host country and last 7) create legitimacy for new nation using 
sports. This can be related to sport diplomacy can help on improving environment of the host country [3].

Wadih Ishac (2018) in his paper "Futhering national development through sport, the case of Qatar" argued that hosting sports mega events can impacts economic, social, political, and environmental of countries. Before today, most countries that hosted a mega sport event did not count on environmental impact. As today, most countries involve trying to transform the event into the green one. Those attempt hences the reducing of the use of carbon, its profit from natural capital. Sport will provide the environmental development like that and lastly, he believes that sport will be able to improve environment development by using popularity of sport to promote awareness [4].

Indonesia itself has often held various friendly sports competitions and also sports parties. Indonesia has also been selected several times to host prestigious sporting parties. In 2018 Indonesia will again be chosen to host the Asian Games, before Indonesia was chosen to host the Asian Games in 1962. At first Hanoi, Vietnam was chosen to host, but with financial reasons Vietnam resigned. This sports party will be held in two cities, Jakarta and Palembang. Provinces around Jakarta such as Banten, West Java, including Bandung, will be involved in supporting the Games [5]. This study aims to examine the sports diplomacy of the 2018 Asian Games in Palembang and Jakarta, more details will be explained in the next section which is the formulation of the problem. Traditional diplomacy can be interpreted as a relationship between a sovereign state by being represented by official agents in a peaceful manner. The practice of diplomacy is a way to achieve each country's foreign policy, in International Relations diplomacy is like the engine room. In general, diplomacy is the antithesis of war. Diplomats can work on promises, try to attract other countries' interests, bargain and try to persuade. Today, traditional diplomacy is rapidly developing and involving sports organizations and sportsmen. The development of this network eventually led to the introduction of a new term namely sports diplomacy. Sports diplomacy eventually became part of public diplomacy. This diplomacy involves representatives and diplomacy activities carried out by sportsmen as representatives of their government[6].

Sports diplomacy practices are facilitated by traditional diplomacy and use sportsmen and sporting events to engage them, inform and make good perceptions among the public and foreign organizations and change their perceptions more conducive to the purpose of meeting the country's foreign policy objectives. Diplomacy through the implementation of big sports is not a new thing, but what we can and should pay more attention to is how globalization has expanded and strengthened the influence of diplomacy as an instrument of branding for the host country. For the holding of this event even the country spent a lot of large funds in the hope of developments in the economic sector, especially in the tourist and tourism sectors. Through this sporting event Indonesia can market Indonesian identity and culture. However, sport is closely related to environmental aspects and community concern for the environment.

Jakabaring Sport City was used as the event site for the Asian Games. Preliminary plans were to increase the size of Gelora Sriwijaya Stadium from 36,000 to 60,000 seats, they were shelved. The site had undergone some renovations, including also being converted from bleachers to an all-seater [7]. A new 40-lane bowling alley was constructed on the complex, as well as eight additional tennis courts [8]. The length of the canoeing and rowing venue in Jakabaring Lake was extended to 2,300 meters, while new rowing facilities and a tribune were built on the lake shore [9]. Other existing venues which were used for Games were also renovated, including Ranau Sports Hall as sepak takraw venue [10]. The Jakabaring sport city include 325 ha land. Here there are Gelora Sriwijaya stadium, Dempo sports hall, Ranau sports hall, jakabaring aquatic stadium, squash field, athletic stadium and warming up field, and many other fields and arenas.

What are the environmental aspects and environmental concerns as part of sports diplomacy in Asian games is an issue that will be examined by researchers. This study aims to study what aspects of the environment and public concern for the environment as part of the Olaraga Diplomacy at the 2018 Asian Games.

\section{Material and Methods}

This research uses exploratory and descriptive methods, aiming to explore or explore to understand a research topic in order to find a truth about the presence or absence of a new event or phenomenon, to illustrate people's views on environmental aspects as sports diplomacy in 2018 Asian Games sporting events. The sampling technique in this study is purposive sampling. A sampling method based on specific objectives, not strata or random. This study will take samples from the general public who enjoy the facilities provided in preparation for the 2018 Asian Games, then the Small and Medium Enterprises (SMEs), artists and street attractions, Palembang Sportsmen, Adolescents who are members of Asian games volunteers and the city government as the executor of preparation for the 2018 Asian Games itself. The methods for distributing questionnaires varied, some were directly asking questions, some were sent via electronic media. Here is a table for an explanation of the variables and dimensions of this study: 
Table 1. Variable and Research Indicators

\begin{tabular}{llll}
\hline Variable & Dimension & Indicators & Source \\
\hline $\begin{array}{l}\text { Environmental aspects and } \\
\text { public concern for the } \\
\text { environment as sports } \\
\text { diplomacy at the 2018 Asian }\end{array}$ & $\begin{array}{l}\text { Environmental } \\
\text { cleanliness aspect }\end{array}$ & $\begin{array}{l}\text { Assessing aspects of environmental } \\
\text { cleanliness }\end{array}$ \\
$\begin{array}{l}\text { Aspects of public } \\
\text { concern for the } \\
\text { environment }\end{array}$ & $\begin{array}{l}\text { Study the public concern for the provided } \\
\text { facilities namely toilet, clean water and } \\
\text { rubbish bin, free smoking zones. }\end{array}$ \\
\hline
\end{tabular}

This study uses an online questionnaire. The online questionnaire in the form of Google Form, began to be activated or distributed on 1 October 2017 at 9:20 WIB and closed on 28 October 2017 at 19:19 WIB. The number of samples taken was 226 respondents. The identity of the respondents were dominated by those with ages between 17 and 21 years old. Most of them were students.

\section{Results and Discussion 3.1 Respondents' Characteristics}

In this study 208 respondents. Of that number there were 86 men (40 percent) and 122 women (60 percent). The dominant age of the respondents is between 17-21 years), with the main occupation being students. Most of the regional origin is from the city of Palembang. All respondents have visited sports venues in Jakabaring Sport City, between 1 time and more than 3 times. On average the respondents know Jakabaring Sport City is through social media and get recommendations or invitations from friends.

\subsection{Availability of Public Facilities in Jakabaring Sport City}

The availability of public facilities that can be used by Jakabaring Sport city visitors during the Asian Games in 2018 are presented in Table 1. Pictures of number public facilities that were built in the sport city for the Asian Games in 2018 were in Figure 1.

Table 1. Public facilities in Jakabaring Sport City

\begin{tabular}{clc}
\hline No. & \multicolumn{1}{c}{ Facilities } & Total \\
\hline 1. & Tap water network & 50 spots \\
2. & Toilets & 30 Units \\
3. & Wheel Bin $(240 \mathrm{ml})$ & 15 Units \\
4. & Infectious Bin $(141)$ & 20 Units \\
5. & Safety Box & 130 Units \\
6. & Medical Waste Plastics & 10 Packs \\
7. & Freezer & 1 Unit \\
8. & Drop Box for Hazardous and Toxic Waste & 2 Units \\
\hline
\end{tabular}



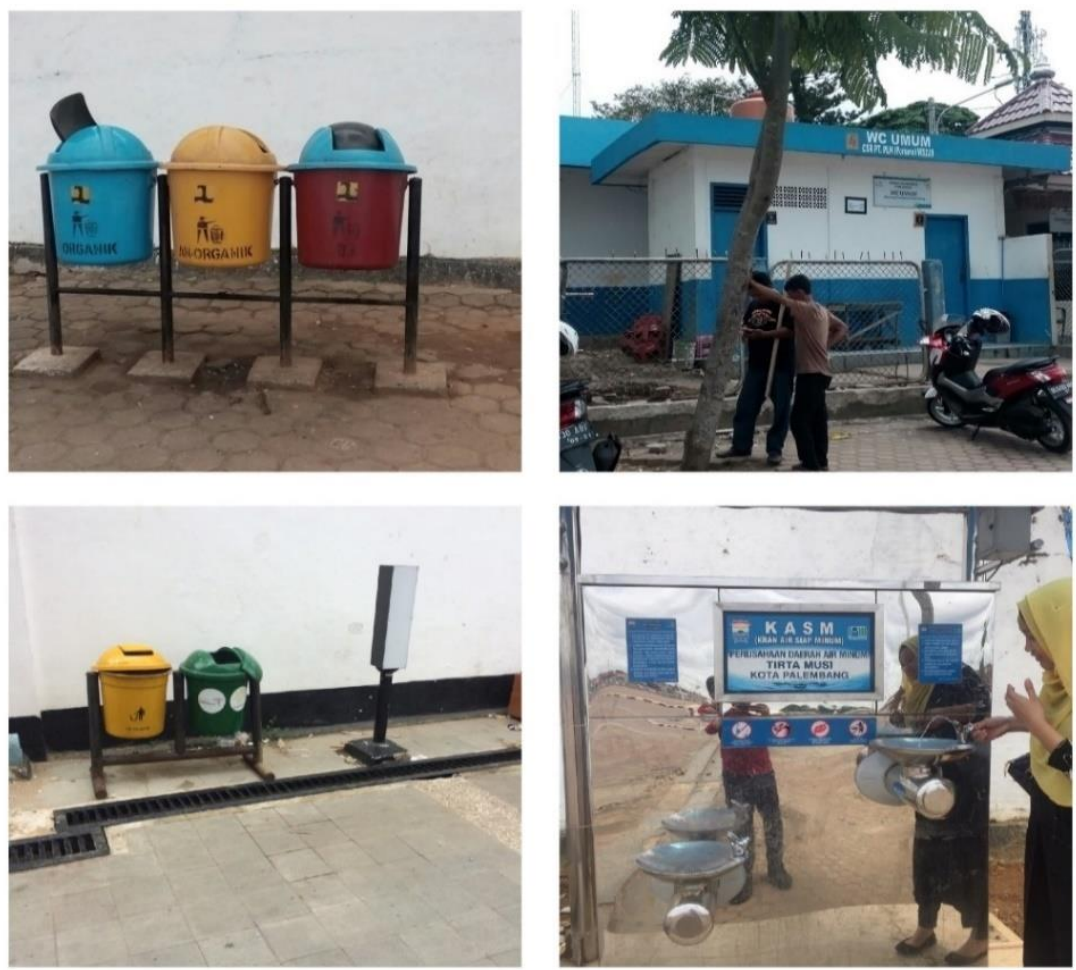

Figure 1. Pictures of public facilities that were built in the sport city.

\subsection{Respondents' Opinions on Environmental aspects}

public facilities. When asked whether the availability of clean water to face the 2018 Asian Games, most respondents thought that it was rather good, good and very good (more than 190 respondents stated that water availability was good or 90 percent of all respondents). Only 10 percent of respondents stated that water availability was inadequate (Figure 2). The author believes that the respondents' concern is a form of their concern that sports diplomacy through the 2018 Asian Games will be successful and not cause environmental problems.

which included the availability of clean water, garbage boxes, availability of public toilets and smoke-free zones. Less than 10 percent of respondents are concerned about the adequacy of clean water and other

\section{Clean Water Reserve}

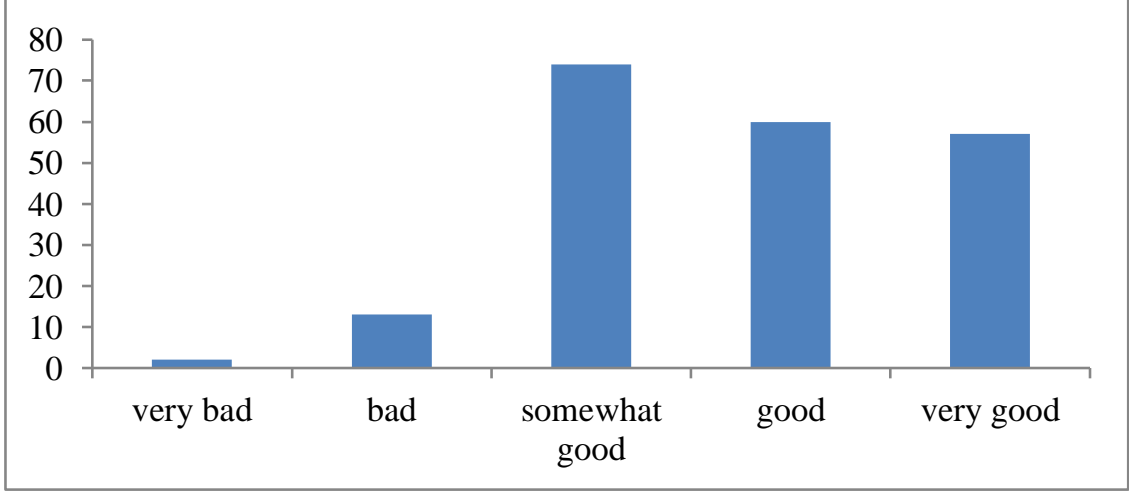

Figure 2. Respondents' opinion on clean water reserve 
When the respondents were asked whether the availability of municipal waste was sufficient to be provided by the 2018 Asian Games committee. There were 58 respondents ( 20 percent of all respondents) that the availability of garbage boxes was far from sufficient. There were 150 respondents ( 80 percent of the total respondents) thought that the availability of garbage boxes was considered adequate (Figure 3). Respondents who were worried that there would be a shortage of garbage boxes during the 2018 Asian Games had a logical reason because they obtained information about the estimated number of visitors at the Asian sporting event. This is also a form of environmental awareness of the respondents. 20 percent of the respondents who want more garbage boxes should be appreciated because it is a form of their concern for the environment.

The availability of toilets was of little concern to the respondents. Only 7 respondents $(0.34$ percent of the total respondents) were concerned about the inadequacy of toilets during the 2018 Asian Games. The remaining 99.66 percent of respondents believed that the number of toilets provided by Asian sports athletes was sufficient (Figure 4). This happens because information about the availability of toilets in venues of all sports is relatively adequate because the city of Palembang had held a Southeast Asian-level sports event in the past few years. Palembang even has hosted sports matches for Islamic countries.

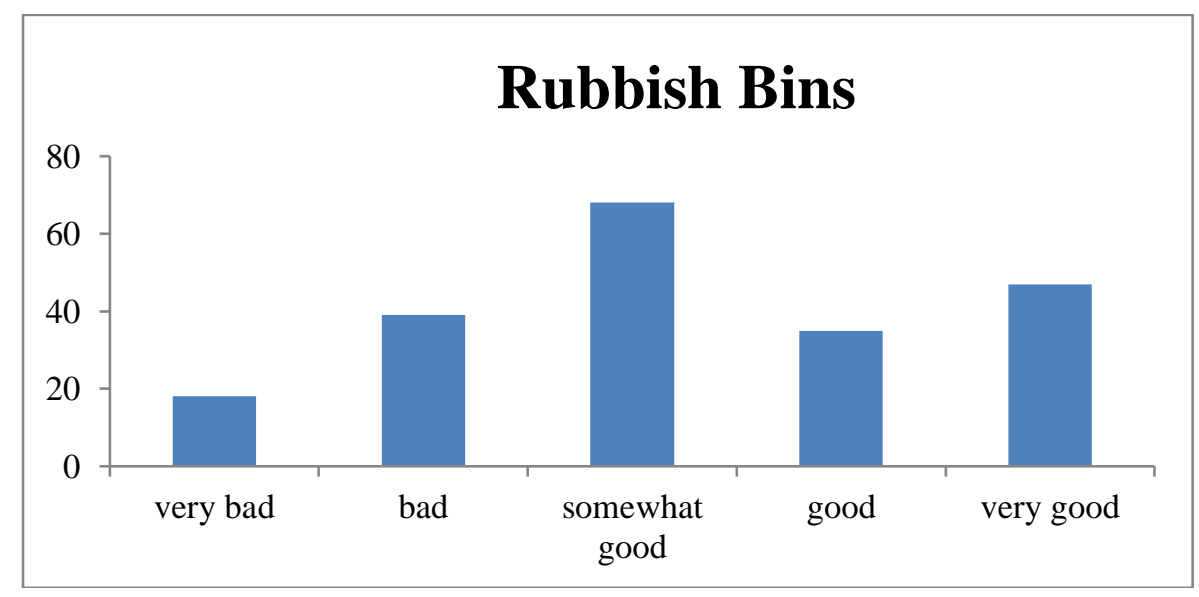

Figure 3. Respondents' opinion on the availability of rubbish bins

The availability of a smoke-free zone is an important matter to consider by the 2018 Asian Games committee. When asked respondents whether a smoke-free zone will be available adequately during the 2018 Asian Games, there are 9.8 percent of all respondents concerned that there is no zone smoke free, although there are 90.2 percent of all respondents who believe that the number of smoke-free zones will be sufficient and well maintained (Figure 5). This is important to note by the committee because of the concern about 10 percent of all respondents are concerned about damage to the good name of the Indonesian people in the eyes of participants from abroad if there are very few smoke-free zones.

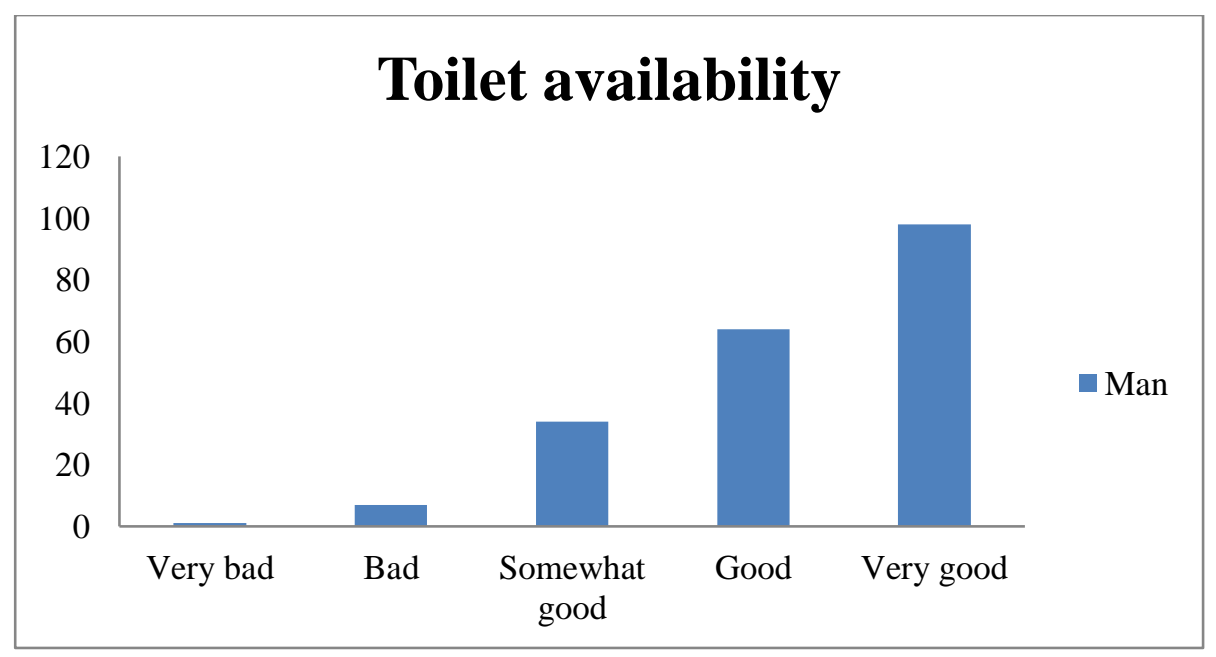

Figure 4. Respondents' opinion on toilet availability 


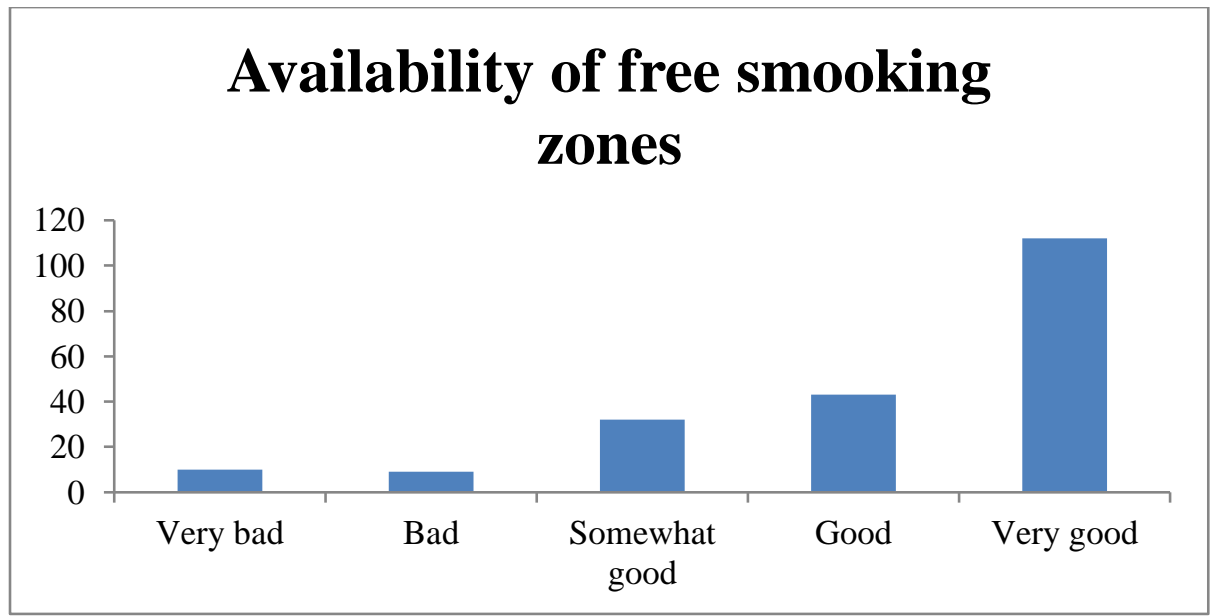

Figure 5. Respondents' opinion on the availability of free smooking zones

Environmental aspects and public concern for the environment in the context of sports diplomacy at the 2018 Asian Games are important to the attention of all parties, especially for the success of the Asian sporting event. The results of this study indicate that several environmental aspects were the focus of the respondents who were asked in this study. First, the availability of public facilities such as toilets, ready-todrink tap water networks, rubbish bins, wheel bins, infectious bins, safety boxes, medical plastic waste and dangerous and toxic waste drop boxes. It turns out that all the facilities are available quite adequately. Second, public concern is reflected in the opinions and concerns of the respondents. Respondents who are still worried about the limited number of toilets, ready-to-drink tap water networks, rubbish bins and other waste management facilities that should receive the attention of the committee of sporting events in Asia. Although many people are confident that the availability of public facilities will not be a problem, but these concerns need special attention from the organizers of the 2018 Asian Games event. Given this sports diplomacy if there is a lack of facilities due to the explosion of visitors will have an impact on the shame of our country in the eyes of the international world. Only what was able to reduce public concerns as triggered by the respondents in this study was the fact that Palembang and Jakarta were accustomed to hosting international sporting events such as the SEA Games and the Islamic Nations Sports Week not long ago.

\section{Conclusion}

It can be concluded from results of the study that all the public facilities were quite good to very

\section{References}

[1] Qingmin, Z. "Sport Diplomacy: The Chinese Experience and Perspective," The Hague Journal of Diplomacy, vol. 8, pp. 211-233, 2013.

[2] Wilson, E. J. Hard Power, Soft Power, Smart good, which included the availability of clean water, garbage boxes, availability of public toilets and smokefree zones. Less than 10 percent of respondents are concerned about the adequacy of clean water and other public facilities. Today, environment has been important issues that most policy makers as well as public and civic agencies concerned. The hosting of mega sports events turns out giving awareness in better understanding on environmental impacts. Most countries want to be host international events to gain profit and so they can speed up the development of hosting city. Indonesia specially Palembang city are implemented strategies that environmentally friendly such as providing clean water and implementing waste avoidance. Even so this study shown us that government need to put more effort on improving environment. To do so, government need to establish more policy and law on management of the environment. Make supporting facilities for environmental protection seem easy, what makes it difficult is to preserve to make it long lasting. Meanwhile public also helping by taking care of all the public facilities as well as helping on take care of the environment. It was suggested that there must be a better management for the public facilities to avoid sortage of clean water, damages of toilets, rubbish bins and others. This study is not covering all the issue of environment and sport diplomacy. There will be needed for more studies on how sport diplomacy has negative impact on environment. To support sport diplomacy, the development is needed, the problem is built without adding pollution is kind of hard job to be done.

Power. The ANNALS of the American Academy of Political and Social Science, Vol. 616, pp.110124. 2008

[3] Trunkos, J. \& Heere “ Sport Diplomacy : A Review of How Sport can be Used to Improve International Relations. In Case Studies in Sport 
Diplomacy, 2015, pp.1-17

[4] Ishac, Wadih. Futhering national development through sport, the case of Qatar, 2018

[5] H. Prasetyo, "Asian Games 2018, Sukses Indonesia 1962 Bisa Jadi Inspirasi," 8 January 2018. [Online]. Available: https://sport.tempo.co/read/1048319/asiangames-2018-sukses-indonesia-1962-bisa-jadiinspirasi/full\&view $=$ ok.

[6] Pambudi, T.L. Peran Publik dalam Diplomasi: Penggunaan Diplomasi Basket dalam Hubungan Amerika Serikat-Cina, Jurnal Analisis Hubungan Internasional, 5(3), pp.111 - 124, 2016

[7] Anonymous. Direnovasi, kapasitas stadion Jakabaring berkurang, November 2017. Accessed on: 12 July 2018. [Online].

Available: https://superball.bolasport.com/read/331435040/ direnovasi-kapasitas-stadion-jakabaringberkurang

[8] Anonymous. Penambahan Lapangan Tenis untuk Asian Games 2017, Agustus 2017.

Accessed on: 12 July 2018. [Online].

Available:

https://www.viva.co.id/foto/sport/19253penambahan-lapangan-tenis-untuk-asian-games$\underline{2017}$

[9] Anonymous, APP Sinar Mas Serahkan Jakabaring Bowling Center, Kompas.com, May 2018. Accessed on: 12 July 2018. [Online]. Available: https://olahraga.kompas.com/read/2018/05/31/04 134958/app-sinar-mas-serahkan-jakabaringbowling-center

[10] Anonymous. Jelang Asian Games, ISTAF Apresiasi Persiapan GOR Ranau, Maret 2018. Accessed on: 12 July 2018. [Online].

Available : https://www.klikampera.com/jelangasian-games-istaf-apresiasi-persiapan-gor-ranau/

[11] Rahim, SE, N. Damiri, dan Ch. Zaman. Lingkungan dan kesehatan. Unsri Press. 2018. 